Studi es of Gene Expressi on in Liver of I nsul i n- Li ke Growth f act or ( I GF) - I , I GF- Bi ndi ng Prot ei $n-3$ and Growth Hor mone( $\mathrm{GH}$ ) Recept or / GH Bi ndi ng Prot ei $n$ i $n$ rats Treat ed Neonat al I y wi th Monosodi um G ut anate

\begin{tabular}{|c|c|}
\hline 著者 & 久保田 晃 \\
\hline 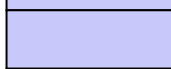 & 浜松医科大学学報. 学位授与記録 \\
\hline 巻 & 11 \\
\hline ページ & 73. 75 \\
\hline 発行年 & $199403-25$ \\
\hline URL & ht t p: //hdl . handl e. net /10271/1027 \\
\hline
\end{tabular}


学位論文の内容の要旨及び論文審查の結果の要旨

\begin{tabular}{|c|c|c|c|}
\hline 学位記番号 & 医博第 174 号 & 学位授与年月日 & 平成 6 年 3 月 25 日 \\
\hline 氏 & \multicolumn{3}{|l|}{ 久保田 } \\
\hline 論文題目 & \multicolumn{3}{|c|}{$\begin{array}{l}\text { Studies of Gene Expression in Liver of Insulin - Like Growth factor (IGF) - } \\
\text { I, IGF - Binding Protein - } 3 \text { and Growth Hormone (GH) Receptor / GH } \\
\text { Binding Protein in rats Treated Neonatally with Monosodium Glutamate } \\
\text { (新生児期グルタミン酸ナトリウム大量投与による成長障害ラットに } \\
\text { おけるインスリン様成長因子(IGF) -I、IGF 結合蛋白-3および成長ホ } \\
\text { ルモン受容体/成長ホルモン結合蛋白の個体発生的遺伝子発現に関す } \\
\text { る研究) }\end{array}$} \\
\hline
\end{tabular}




\section{医学博士 久保田晃}

\section{論文题目}

Studies of Gene Expression in Liver of Insulin-Like Growth factor (IGF) -I, IGF-Binding Protein-3 and Growth Hormone (GH) Receptor/GH Binding Protein in rats Treated Neonatally with Monosodium Glutamate

（新生児期グルタミン酸ナトリウム大量投与による成長障害ラットにおけるインスリン様成長因子 (IGF) - I 、IGF 結合蛋白ー 3 および成長ホルモン受容体／成長ホルモン結合蛋白の個体発生的 遗伝子発現に関する研究）

\section{論文の内容 の要旨}

目的

新生児期のラットに大量のグルタミン酸ナトリウム（MSG）を注射すると視床下部弓状核に選択的 に病変を作る。これにより、GH 放出ホルモン（GHRH）産生神経線維をほぼ完全に破壊し、GHRH 分泌不全の成長障害モデルを作成ずることが出来る。この MSG ラットにおいて視床下部・下垂体を中 心に多くの検討がなされているが、その病変による末梢組織におけるホルモン動拍についてはほとんど 明らかにされていない。

そこで、雄、雌両方 MSG ラットを用い正常対照群と比較することにより、中枢の障害による $\mathrm{GH}$ 分泌動態の変化が肝の IGF-I、GH 受容体 (GHR) / GH 結合蛋白 (GHBP) の遗伝子発現に 成長段階でどのような影響を及ぼすか、さら GH 依存性といわれる IGF 結合蛋白ー3（IGFBP-3） に対して影部があるかを検討した。

方法

MSG ラット作成のために Sprague-Dawley ラットを用い、出生後 2、4、6、8、10日目に MSG を $4 \mathrm{mg} / \mathrm{g}$ 体重または正常対炤群として $10 \% \mathrm{NaCl} 0.01 \mathrm{ml} / \mathrm{g}$ 体重 皮下注射した。生後 2、4、 6、8、10、12週目に断頭して血清と肝臟を探取した。血清は酸エタノール処理で結合蛋白を除去した

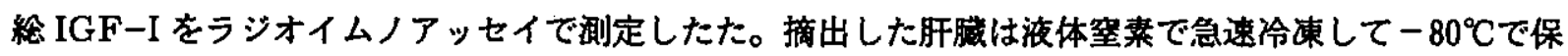
存し、acid guanidinium thiocyanate phenol chloroform 法に proteinase K 処理を加えて total RNA を抽出した。抽出したRNA はグリオキサールで変性後、ノーザンまたはドットフロットにてナ イロンメンフレンに転写し、 ${ }^{32} \mathrm{P}$ で標識したラットIGF-I cDNA、ラットGHR/GHBP cDNA ま たはラットIGFBP-3 cRNAをプローフとしハイブリダイズさせた。終了後、X 線フィルムに感光 させデンシトメトリーで定量化した。有意差検定は $\mathrm{t}$ 一検定を用いた。

結果

1） MSG ラットは対照群に此べ、生後 6 週より体重、尾長ともに小さく、成長障害を示した。特に、 雄は雌より成長障害の程度が強く統計的に有意だった。生後12週では婎、雌ともに肥满傾向を認め MSG ラット特有の体型を示した。

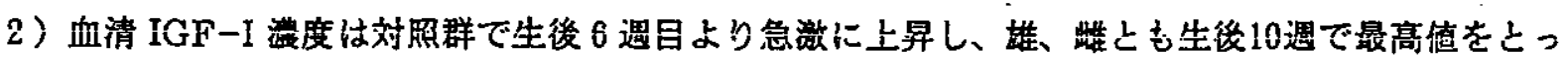
た。一方、MSG ラットでは上昇は緩徐で、生後 6 週より有意に低く、生後 10 週で対照群の約 $45 \%$ だった。

3 ）覓伝子発現は対照群の生後 2 週を基準として、雄と睢を別々に検討した。

IGF-I の透伝子発現は唯は両群ともに生後 4 週から強くなり、生後10週からやや減弱した。一 
方、雄は両群とも生後 6 週から強くなり、対照群は高い発現を維持したが、MSG 群では生後12週 にやや減弱した。 MSG 群では雄、雌とも生後 4 週より対照群に比べ有意に低い発現だった。

4) IGFBP-3 の造伝子発現は雄では各週路でほぼ一定で、両群に差がみられなかった。しかし、雌 では対照群は雄之同様にほぼ一定の景伝子発現を示したのに対し、MSG 群では生後 6 ～ 8 週で対 照群に比べ約50\%減少を示した。

5) GHR/GHBP の遗伝子発現においては、雌では GHR の発現が MSG 群で対炤群に比べ弱かっ たが、GHBP の発現はほぼ同じだった。一方、雄では MSG 群と対照群で GHR の発現はほぼ同 じだったが、GHBP の発現は MSG 群で強かった。

\section{考案・結語}

IGF-I、GHR/GHBP の速伝子発現は GH 分泌に㑈存し、特に GHR/GHBP の発現は GH 分泌 動热之関連し、GH の基砚值が高いと GHR の発現が增強し脈動性分泌が少ないと GHBP の発現が增 強すると言われている。MSG ラットにおけるIGF-I、GHR/GHBP の造伝子発現は視床下部障宫 の GH 分泌の低下を忠実に表現し、成長陵害のモデとして有用と思われた。IGFBP-3 は常に血中 でIGFと結合しているので GHにより IGF と同じ制御を受けていると考えられてきたか、今回の検討 により MSG ラットの雄ではIGFBP-3 の遗伝子発現はほとんど影響を受けないことが分かった。し かし、雌では MSG ラットと対照群と異なる発現を示しており、IGFBP-3の遺伝子発現に関しては GH の関与も考えられた。

\section{論文審査の結果の要旨}

新生児期のラットに大量のグルタミン酸ーナトリウム（MSG）を投与すると視床下部弓状核に選択 的に病変ができる。GH 放出ホルモン (GHRH) 産生神経細胞がほぼ完全に破壊されるので、この方 法を用いて、GHRH 分䎵不全の成長障害モデルラットを作成することができる。そこで申誚者は、こ の成長障害モデルラットを用いて、中枢での GH 分祕の変化がその支配下にある末梢組織におけるホ ルモン動態によ゙のような影謷を与えるかを明らかにしようとした。成長障害モデルラットは、出生後 2、4、6、8、10日目にそれぞれ $4 \mathrm{mg} / \mathrm{g}$ 体重の MSG を投与することにより作成し、対炤ラット には MSG の代わりに10\% NaCl を投与した。生後 2、4、6、8、10、12週目に屠殺し、血清中イ ンスリン様成長因子I（IGF-I）のレベルをラジオイムノアッセイで、肝腀 IGF-ImRNA、GH 受容 体（GHR）/GH 結合蛋白（GHBP）mRNA、IGF 結合蛋白一 3 （IGFBP-3）mRNA をノ一 ザンまたはドットブロット法で測定した。

実験の結果、成長障害ラットでは生後 6 週以降において、体重、尾長共対照群より小であり、成長障 害を示した。成長障害の度合は雄の方が雌より大であった。血清 IGF-I 潧度は、対照群で生後 6 迵よ り急激に上昇し、生後10週で最高值となったが、成長障害モデルラットでは上昇が緩徐で且つ低值（生 後10莮で対照群の45\%) であった。肝臟のIGF-ImRNA、GHR/GHBPmRNA、IGFBP- $3 \mathrm{mR}$ NAの経時変動に関しては図に示したデータが得られた。雄と雌でかなり巽なる挙動が観察されたが、 それぞれの性の中で成長障害もテルラットと対照群を比較すると、IGF-I と GHR/GHBPに関して はその遭伝子発現が視㦿下部障害による GH 分祕の低下をかなり忠実に反映していることが示唆され た。しかし、常に IGF と結合しているのでIGF と同じ制御を受けると考えられている IGFBP-3の mRNA レベルが、少なくとも雄では GH 分祕低下の影震を受けないのは興味深い発見であった。 


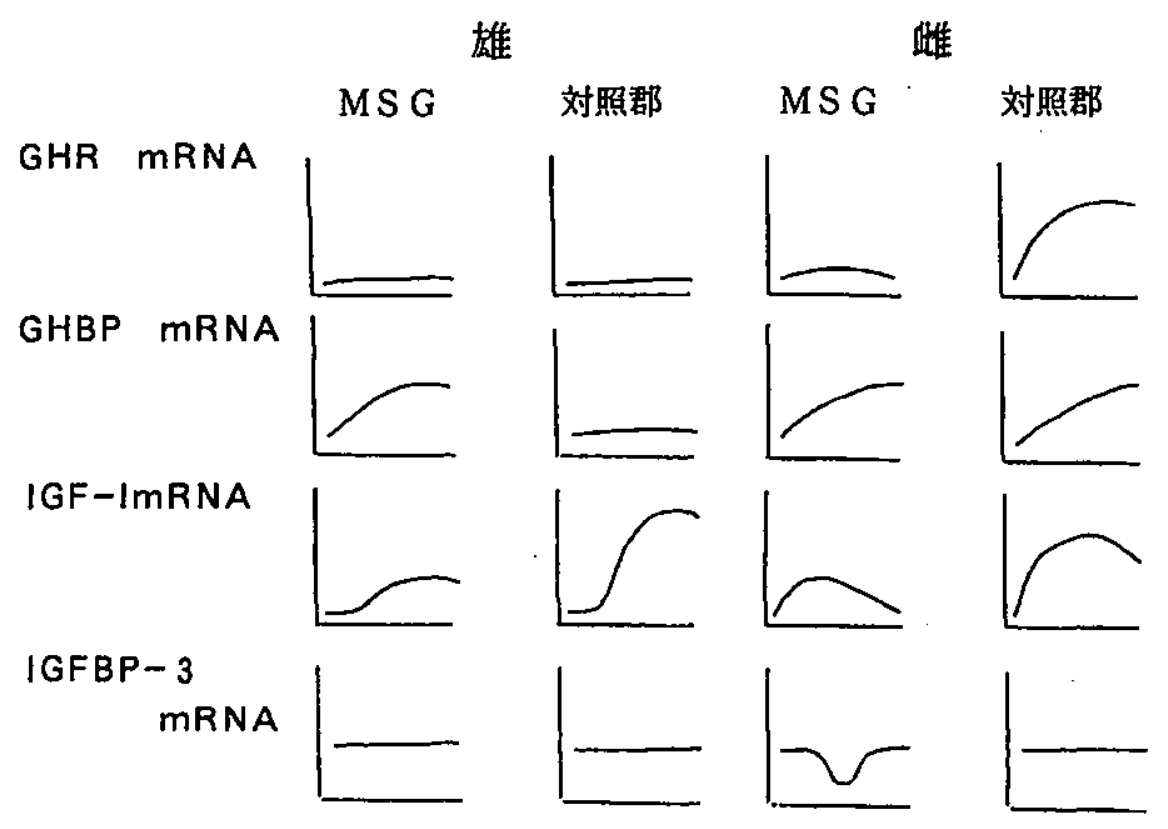

生後過数

雷查委員会では、以上の内容の研究発表と関連して次の試問を行った。

1.グルタミン酸ーナトリウムの作用機構、および弓状核 GHRH 細胞に特異的に作用するとすればそ の理由

2. GH 欠乏成長障害モデルラットで生後 6-8 週におけるIGF-I の增加を促している因子について

3. GH 分泌のパターンの雄、雌差の理由、および今回の実駼で観察された雄、雌差と GH 分泌パ ターンの驻、雌差の因果関係、GH の持続投与と間欠投与では勃果が異なるか、異なるとすればそ の理由等

4. GHR と GHBP の虺い、GHBP の生合成過程、種類、所在、機能、および GHBP と結合した GH の活性

5. GHR 由来の GHBP と本来の（GHBPmRNA に由来する）GHBP の異同、識別法等

6. 対照群で、GHRmRNA も GHBPmRNA も雄では雌より低值であることの理由

7. GHBPの血清レベルと GHR の機能の関連、先端巨大症の GHBP レベル、GHBP の日内リズム の有無等

8 .IGFBP の種類と機能、GH 依存性 IGF-IGFBP の血中での存在様式、およびその中の “acid-labile subunit" の由来と役割

9. 申請者の実験係での血中 IGFBP のレベル

これらの質問にたいする申誚者の応答は適切之認められ、本論文が博士（医学）の学位に値する内容 を備えていると蕃查員全貣一致で判定した。

論文蕃查担当者 主査 教授 市山 新

副查教授藤 田道也副查 教授吉見 輝也

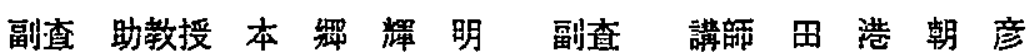

